\title{
Effect of metal oxide based TiO2 nanoparticles on anaerobic digestion process of lignocellulosic substrate
}

Ghofrani-Isfahani, Parisa; Baniamerian, Hamed; Tsapekos, Panagiotis; Alvarado-Morales, Merlin; Kasama, Takeshi; Shahrokhi, Mohammad; Vossoughi, Manouchehr; Angelidaki, Irini

\section{Published in:}

Energy

Link to article, DOI:

10.1016/j.energy.2019.116580

Publication date:

2020

Document Version

Peer reviewed version

Link back to DTU Orbit

Citation (APA):

Ghofrani-Isfahani, P., Baniamerian, H., Tsapekos, P., Alvarado-Morales, M., Kasama, T., Shahrokhi, M., Vossoughi, M., \& Angelidaki, I. (2020). Effect of metal oxide based $\mathrm{TiO}$ nanoparticles on anaerobic digestion process of lignocellulosic substrate. Energy, 191, [116580]. https://doi.org/10.1016/j.energy.2019.116580

\section{General rights}

Copyright and moral rights for the publications made accessible in the public portal are retained by the authors and/or other copyright owners and it is a condition of accessing publications that users recognise and abide by the legal requirements associated with these rights.

- Users may download and print one copy of any publication from the public portal for the purpose of private study or research.

- You may not further distribute the material or use it for any profit-making activity or commercial gain

- You may freely distribute the URL identifying the publication in the public portal 


\section{Journal Pre-proof}

Effect of metal oxide based $\mathrm{TiO}_{2}$ nanoparticles on anaerobic digestion process of lignocellulosic substrate

Parisa Ghofrani-Isfahani, Hamed Baniamerian, Panagiotis Tsapekos, Merlin

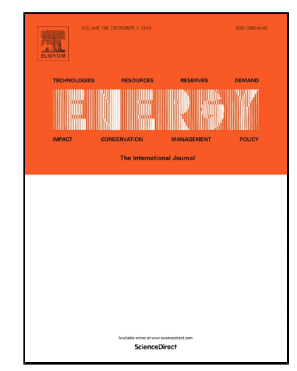
Alvarado-Morales, Takeshi Kasama, Mohammad Shahrokhi, Manouchehr Vossoughi, Irini Angelidaki

PII: S0360-5442(19)32275-3

DOI: https://doi.org/10.1016/j.energy.2019.116580

Reference: EGY 116580

To appear in: Energy

Received Date: 08 November 2018

Accepted Date: 19 November 2019

Please cite this article as: Parisa Ghofrani-Isfahani, Hamed Baniamerian, Panagiotis Tsapekos, Merlin Alvarado-Morales, Takeshi Kasama, Mohammad Shahrokhi, Manouchehr Vossoughi, Irini Angelidaki, Effect of metal oxide based $\mathrm{TiO}_{2}$ nanoparticles on anaerobic digestion process of lignocellulosic substrate, Energy (2019), https://doi.org/10.1016/j.energy.2019.116580

This is a PDF file of an article that has undergone enhancements after acceptance, such as the addition of a cover page and metadata, and formatting for readability, but it is not yet the definitive version of record. This version will undergo additional copyediting, typesetting and review before it is published in its final form, but we are providing this version to give early visibility of the article. Please note that, during the production process, errors may be discovered which could affect the content, and all legal disclaimers that apply to the journal pertain.

(c) 2019 Published by Elsevier. 


\section{Effect of metal oxide based $\mathrm{TiO}_{2}$ nanoparticles on anaerobic digestion process of lignocellulosic substrate}

Parisa Ghofrani-Isfahani ${ }^{\mathrm{a}, \mathrm{b}, 1}$, Hamed Baniameriana, ${ }^{\mathrm{a}, \mathrm{d}}$, Panagiotis Tsapekos ${ }^{\mathrm{a}}$, Merlin Alvarado-Morales ${ }^{\mathrm{a}}$, Takeshi Kasamac ${ }^{\mathrm{c}}$, Mohammad Shahrokhi ${ }^{\mathrm{b}, *}$, Manouchehr Vossoughi $^{\mathrm{b}}$, Irini Angelidaki ${ }^{\mathrm{a}, *}$

a Department of Environmental Engineering, Technical University of Denmark, Kgs. Lyngby, DK-2800, Denmark

${ }^{b}$ Department of Chemical and Petroleum Engineering, Sharif University of

Technology, P.O. Box 11365-9465, Azadi Ave., Tehran, Iran

c Center for Electron Nanoscopy, Technical University of Denmark, Kgs. Lyngby, DK2800, Denmark

${ }^{\mathrm{d}}$ Department of Chemical Technologies, Iranian Research Organization for Science and Technology (IROST), Tehran, Iran

${ }^{1}$ These authors contributed equally

${ }^{*}$ Corresponding authors:

Irini Angelidaki

Department of Environmental Engineering, Technical University of Denmark

Bld 115, 2800 Lyngby Denmark

E-mail: iria@env.dtu.dk,

Tel.: +4545251429 ; fax: +4545932850

Mohammad Shahrokhi

Department of Chemical and Petroleum Engineering, Sharif University of Technology, 
P.O. Box 11365-9465, Azadi Ave., Tehran, Iran

E-mail: shahrokhi@sharif.edu

Tel: +982166165419 


\begin{abstract}
Lignocellulosic materials are recalcitrant to bioconversion, due to their rigid physiochemical structure. In this work, the effects of $\mathrm{Fe}_{2} \mathrm{O}_{3}-\mathrm{TiO}_{2}$ and $\mathrm{NiO}-\mathrm{TiO}_{2}$ nanoparticles (NPs) and $\mathrm{FeCl}_{3}$ and $\mathrm{NiCl}_{2}$ salts, on the anaerobic digestion (AD) of wheat straw have been investigated. For this purpose, metal oxide- $\mathrm{TiO}_{2} \mathrm{NPs}$ were synthesized and fully characterized. Results showed that addition of $0.252 \mathrm{mg}$ of NiO$\mathrm{TiO}_{2} / \mathrm{g}$ total solids (TS) to batch assays resulted in increase of soluble chemical oxygen demand (COD) and 67\% increase in volatile fatty acids (VFAs) concentration compared to control tests during the first 4 days of experiments. These results indicate that hydrolysis and acidogenesis rates have been enhanced due to addition of NPs. No significant effects have been observed in soluble COD and VFAs concentrations compared to control experiments by adding salts to the batch assays. Addition of NPs or salts led to an increase in methane production rate during the first 4 days of experiments.
\end{abstract}

\title{
Keywords
}

Nanoparticles; Anaerobic digestion; Lignocellulose; $\mathrm{TiO}_{2}$; Trace elements

\section{Introduction}

In recent years, interest in anaerobic digestion (AD) of organic waste such as cow manure, poultry litter, food waste, and agriculture residues has increased. The AD process can contribute to treatment of organic wastes, and at the same time produce a renewable fuel (biogas) and thereby contribute to reduction emission of greenhouse gases [1]. Four major steps are involved in biological conversion of organic matters to 
biogas. Different groups of microorganisms perform the four steps, i.e., hydrolysis, acidogenesis (primary fermentation), acetogenesis (secondary fermentation), and methanogenesis during AD of organic matters [2]. Among various types of feedstocks, lignocellulosic materials, i.e. agriculture residue, can be potentially one of the important substrates in AD process, due to their availability, large abundance and high carbohydrate content [3]. Generally, The hydrolysis of lignocellulosic biomass to fermentable substances is considered the rate limiting step in overall process [4]. So in order to increase the overall biogas production rate, accelerating hydrolysis step is necessary. Anaerobic thermophilic hydrolytic bacterium such as Clostridium thermocellum produces extracellular enzymes and perform the initial break down of cellulose polymers [5]. In order to facilitate the hydrolysis of lignocellulosic biomass many strategies have been implemented, such as co-digestion with other substrates, chemical or physical pre-treatments and/or combination of them [6], and addition of biological (i.e. enzymes) and non-biological additives (i.e. metal salts of trace elements, metallic and non-metallic nanostructures) to the $\mathrm{AD}$ system [7,8]. Most of the present AD processes dealing with lignocellulosic feedstocks rely on chemical/physical pretreatments and high dosage of enzymes, which can lead to high operational costs of the plant[3]. Liu et al. [9] stated that the addition of external inorganic compounds, i.e. magnetite and zeolite, increased methane production via influencing the microorganisms and enzymatic transformation of the $\mathrm{AD}$ processes.

The activity and growth of AD microorganisms highly depend on necessary nutrients and presence of micronutrients such as the trace elements iron $(\mathrm{Fe})$, nickel $(\mathrm{Ni})$, molybdenum (Mo), cobalt (Co), and selenium (Se) which are constituent of enzymes of microorganisms and are essential for numerous reactions [10]. It has been shown that 
the biogas production from agriculture residues can be limited by the shortage of essential trace elements. However, high concentrations of trace elements can result in adverse effects on biological degradation processes in anaerobic reactors [11]. Lignocellulosic biomass contains low concentrations of trace metals and thereby can potentially lead to low performance of overall AD process. Kim et al. [12] reported that $\mathrm{Fe}, \mathrm{Co}$, and Ni stimulate hydrolysis at both mesophilic and thermophilic temperatures. Generally different methanogens can be activated by specific trace metals, although all methanogens require $\mathrm{Co}, \mathrm{Ni}$ and $\mathrm{Fe}[13]$. Fe is an inorganic cofactor for some proteins (i.e. cytochromes) that are relating to energy metabolism, hence it is essential for the growth of almost all microorganisms involved in AD process [14]. Ma et al. [15] showed that various types of iron oxide $\left(\mathrm{Fe}_{2} \mathrm{O}_{3}, \mathrm{FeO}(\mathrm{OH}), \mathrm{Fe}_{3} \mathrm{O}_{4}\right)$ increase hydrolytic efficiency and methane production from lignocellulosic biomass via generating $\mathrm{Fe}^{2+}$ ion that served as nutrient supply for the microorganisms. Moreover, Zhang et al. [16] reported that iron oxides promoted microbial hydrolysis-acidification of complex organic matter, resulting in more soluble organic matter for methanogenesis. Addition of $30 \mathrm{mg} / \mathrm{g} \mathrm{VS}$ of $\mathrm{FeCl}_{3}$ during $\mathrm{AD}$ of corn straw was also reported to result in an increase of $14 \%$ in methane production [17]. Ni is an essential element of $\mathrm{F}_{430}$, a low molecular weight coenzyme, present in all methanogens which facilitate methane production. Furthermore, Ni is also essential for the growth of acetoclastic organisms [18]. It was reported that the biogas production from manure could be enhanced by addition of $\mathrm{NiCl}_{2}$ [11]. Oppositely, high level of trace elements can have adverse effect on anaerobic digestion process. For instance, it has been reported that $1 \mathrm{mg} / \mathrm{L}$ of Ni was inhibiting AD of sewage sludge [19]. Several researches, recommended concentration of $\mathrm{Fe}$ and $\mathrm{Ni}$ elements in anaerobic digesters was reported in the range of $1-10 \mathrm{mg} / \mathrm{L}$ and 
0.005-0.5 mg/L, respectively [20-23]. Kloss et al. [24] reported that Fe dose of 10-200 $\mathrm{mg} / \mathrm{L}$ increased the cumulative $\mathrm{CH}_{4}$ production. Zhang et al. [25] mentioned that the process related to methane production is inhibited when Ni concentrations exceed 1.2 $\mathrm{mg} / \mathrm{L}$. Altas [26] and Wu et al. [27] reported that 0.5-16 mg/L of Ni increased the cumulative $\mathrm{CH}_{4}$ production. Demirel and Scherer [28] stated that the optimum or stimulatory concentrations of $\mathrm{Ni}$ for batch cultures of methanogens range between 0.012 and $5 \mathrm{mg} / \mathrm{L}$.

Nanoparticles (NPs), with at least one dimension less than $100 \mathrm{~nm}$, have widely been applied in engineering and environmental processes [29]. NPs have excellent thermal, mechanical, structural, and morphological properties which enable them to be used in different environmental applications [30]. The challenges of sustainability, energy, climate change are attracting researchers to explore the nanoscale science as a new source of improvements for the energy and environment section since the nanoscale materials show extraordinary properties that are not shown by bulk materials [31]. NPs, due to their small size, can pass across biological barriers and influence uptake, absorption, distribution and metabolism of compounds [32]. The positive effect exerted by the NPs was explained by their high surface area, high reactivity, high specificity, self-assembly and dispersibility [33]. It has been proven that supplementation of trace elements in form of NPs improved AD performance [34]. On the other hand, the effluent of the $\mathrm{AD}$ process, i.e. digestate, can be used as compost and soil conditioner after dewatering [35]. In some cases, the digestate may become inappropriate and toxic to be applied as a bio-solid due to the accumulation of NPs. Yang et al. [36] showed that silver ions released to soil can lead to a significant reduction in denitrification activity which is unfavourable. The effects and fate of NPs in effluent of AD processes have not 
yet been established completely, therefore digested containing NPs should be investigated in relation to phytotoxicity and bacterial toxicity should be assessed before reusability of bio-solid. One of the advantageous properties of NPs is the slow dissolving rate of trace elements which facilitates the bioavailability of metal ions in the AD medium and enhances enzymes activity [1]. In general, adsorption of NPs on enzymes will cause conformational transitions, accompanied by the inhibition or enhancement of the enzymatic activity [37]. Wang et al. [29] reported that in case of waste activated sludge, $10 \mathrm{mg} / \mathrm{g}$ TS of nano-zero valent iron (NZVI) and $100 \mathrm{mg} / \mathrm{g}$ TS of $\mathrm{Fe}_{2} \mathrm{O}_{3}$ NPs increased the population of microorganisms (Bacteria and Archaea) and activities of key enzymes, while $500 \mathrm{mg} / \mathrm{g}$ TS of $\mathrm{Ag}$ and MgO NPs inhibited them. Abdelsalam et al. [11] reported that during AD of raw manure, using $2 \mathrm{mg} / \mathrm{L}$ of Ni NPs gave the highest specific methane production in comparison to other tested concentrations $(0.5,1$, and $2 \mathrm{mg} / \mathrm{L})$, their salts $\left(\mathrm{CoCl}_{2}\right.$, and $\left.\mathrm{NiCl}_{2}\right)$ and the control. The stimulating effects of NPs may be attributed to their uptake inside the microorganisms, integrating them with metabolic intermediates and key enzyme activities involved in the $\mathrm{AD}$ process [38]. However, the relatively high density of NPs of trace elements (Fe and Ni) may cause an uneven dispersion in the AD medium, which could limit the bioavailability of the trace element and weaken the interaction between iron oxide minerals and functional microorganisms [39]. Coating the trace metal oxides, i.e. iron oxide and nickel oxide, on a carrier may be a potential strategy to solve this problem [40]. Distributing-or coating of metal oxide NPs over the inert support materials (i.e. $\mathrm{TiO}_{2}, \mathrm{Al}_{2} \mathrm{O}_{3}, \mathrm{SiO}_{2}$ ), increases the fraction of surface- exposed atoms of NPs and consequently increases the reactivity of these metals due to desire dispersion of metal oxides on surface of support [41]. Despite this interest, a few researchers have studied 
the effect of supported NPs and to the best of the authors knowledge no one used $\mathrm{TiO}_{2}$, as carrier/support of NPs in AD processes. $\mathrm{TiO}_{2}$ is a kind of inexpensive and noncytotoxic mineral with a large surface area and crystalline structure that can be used as support of trace element NPs. Gonzalez-Estrella [42] reported that among four metal oxide NPs $\left(\mathrm{TiO}_{2}, \mathrm{Al}_{2} \mathrm{O}_{3}, \mathrm{SiO}_{2}\right.$ and $\left.\mathrm{ZnO}\right)$ only $\mathrm{ZnO}$ show inhibitory effect on methane generation. This is mainly due to the release of toxic divalent $\mathrm{Zn}$ ions that influence the microorganisms. In another research Garcia et al. [43] observed no inhibitory effect on $\mathrm{AD}$ of cellulose substrate due to addition of bare $\mathrm{TiO}_{2}$.

Higher degradability and thus, methane production was achieved using a fibre-rich feedstock in thermophilic compared to mesophilic conditions [44]. Furthermore, the thermophilic AD process can lead to improved process performance at increased loading rates and also, produces a more organically-stable, pathogen-free digestate than mesophilic [45]. The mentioned characteristics settle thermophilic AD interesting for real-life applications and hence, the present study was conducted at $55^{\circ} \mathrm{C}$. In the present work, $5.0 \mathrm{wt} \% \mathrm{Fe}_{2} \mathrm{O}_{3}$-coated $\mathrm{TiO}_{2}$ and $5.0 \mathrm{wt} \% \mathrm{NiO}$-coated $\mathrm{TiO}_{2} \mathrm{NPs}$ were synthesized by ultrasonic-assisted co-precipitation method. Batch experiments (BMPs) were conducted under thermophilic conditions, with the purpose of evaluating the effect of the $\mathrm{Fe}_{2} \mathrm{O}_{3}-\mathrm{TiO}_{2}$ and $\mathrm{NiO}-\mathrm{TiO}_{2} \mathrm{NPs}$ on the $\mathrm{AD}$ of wheat straw. For comparison, the experiments with no additive, i.e. control, and with metal salts, i.e. $\mathrm{FeCl}_{3}$ and $\mathrm{NiCl}_{2}$, as the bulk trace elements were also conducted. Chemical oxygen demand (COD), volatile fatty acids (VFAs), and cumulative biogas and methane production, were measured along the $\mathrm{AD}$ process to detailed investigation of the effect of trace elements in form of NPs and corresponding salts, on AD of lignocellulosic feedstock. 


\section{Materials and methods}

\subsection{Substrate and inoculum}

Wheat straw was obtained from an agriculture farm in Zealand, Denmark. The wheat straw was cut down to 1-2 cm length by a cutting mill (Retsch SM 2000) and used as mono substrate in this study. As inoculum the digestate of a well performing lab-scale reactor fed with source separated municipal waste was used. The digestate was sieved in order to remove remaining organic particles. The digestate was degassed before use, by incubating at thermophilic conditions $\left(54 \pm 1{ }^{\circ} \mathrm{C}\right)$ for 10 days to reduce the background biogas production. The physiochemical analysis of wheat straw and inoculum were performed in triplicate and presented in Table 1.

Table 1. Physicochemical characterization of wheat straw and inoculum

\begin{tabular}{ccc}
\hline Characteristics & Wheat Straw & Inoculum \\
\hline $\mathrm{pH}$ & - & 8.08 \\
Total COD $(\mathrm{g} / \mathrm{kgTS})$ & $1060.92 \pm 43.26$ & $24.78 \pm 1.19$ \\
$\mathrm{TS}(\mathrm{g} / \mathrm{kg})$ & $928.39 \pm 0.01$ & $26.70 \pm 0.20$ \\
VS (g/kg) & $867.22 \pm 3.85$ & $17.54 \pm 0.22$ \\
total Kjeldahl nitrogen (TKN) & $4.8 \pm 0.1$ & \\
$(\mathrm{~g} / \mathrm{kg})$ & & \\
ammonium nitrogen (NH4 N) & & \\
$(\mathrm{g} / \mathrm{kg})$ & $0.8 \pm 0.1$ & $1.72 \pm 0.05$ \\
Fe (mg/g TS) & & \\
Ni (mg/g TS) & $0.0009 \pm 0.0001$ & $0.00245 \pm 0.00012$ \\
cellulose (\%TS) & $42.02 \pm 0.72$ & -
\end{tabular}


hemicellulose (\%TS) $\quad 30.75 \pm 0.55$

klason Lignin (\%TS) $\quad 26.73 \pm 2.35$

\subsection{Preparation of metal oxide- $\mathrm{TiO}_{2}$ nanoparticles}

For synthesizing $\mathrm{TiO}_{2}$-based metal oxides, $5.0 \mathrm{wt} \% \mathrm{NiO} / \mathrm{TiO}_{2}$ and $5.0 \mathrm{wt} \%$ $\mathrm{Fe}_{2} \mathrm{O}_{3} / \mathrm{TiO}_{2}$, a sono-chemical method was applied [46]. Diluted ammonia solution was added to $0.5 \mathrm{M} \mathrm{TiCl}_{4}$ solution under stirring and ultrasonication for $120 \mathrm{~min}$ at $80{ }^{\circ} \mathrm{C}$. After cooling down to room temperature, the slurry was centrifuged and washed several times with distilled water. $\mathrm{TiO}_{2}$ powder was collected and dried overnight at $100{ }^{\circ} \mathrm{C}$. In order to coat the surface of $\mathrm{TiO}_{2}$ with $5 \mathrm{wt} \%$ metal oxide $\left(\mathrm{NiO}\right.$ or $\left.\mathrm{Fe}_{2} \mathrm{O}_{3}\right), \mathrm{TiO}_{2}$ powder was introduced to pre-calculated amount (twice the stoichiometric amount) of $\mathrm{Na}_{2} \mathrm{CO}_{3}$ aqueous solution. Then the pre-calculated amount of metal salt, i.e. $\mathrm{NiCl}_{2}$ in the case of $\mathrm{NiO}$ and $\mathrm{FeCl}_{3}$ in case of $\mathrm{Fe}_{2} \mathrm{O}_{3}$, was dissolved in distilled water and metal containing solution was gradually added to $\mathrm{TiO}_{2}$ slurry under stirring and ultrasonication for 120 minutes. The metal oxide- $\mathrm{TiO}_{2} \mathrm{NPs}$ were centrifuged and washed several times with distilled water, following by overnight drying at $100{ }^{\circ} \mathrm{C}$. Finally, the NPs were calcined at $250{ }^{\circ} \mathrm{C}$ at a rate of $5^{\circ} \mathrm{C} / \mathrm{min}$ for $3 \mathrm{~h} . \mathrm{Fe}_{2} \mathrm{O}_{3}-\mathrm{TiO}_{2}$ and $\mathrm{NiO}-\mathrm{TiO}_{2} \mathrm{NPs}$ are denoted as FT and NT, respectively.

\subsection{Characterization of synthesized nanoparticles}

X-ray powder diffraction (XRD) patterns of the synthesized metal oxide- $\mathrm{TiO}_{2} \mathrm{NPs}$ were recorded using a Philips Analytical (X'pert Pro MPD) X-ray powder diffractometer with $\mathrm{CuK} \alpha$ radiation. The average crystallite size of the NPs were calculated using the Scherrer's equation [47].

Brunauer-Emmett-Teller (BET) specific surface area of NPs was measured by $\mathrm{N}_{2}$ 
physical adsorption, using micrometrics Gemini surface area analyzer. Assuming spherical particle, the approximate average particle size of NPs was calculated using the following equation:

$d_{B E T}=\frac{6000}{\rho \times S_{B E T}}$

where $\mathrm{S}_{\mathrm{BET}}$ is the BET surface area $\left(\mathrm{m}^{2} / \mathrm{g}\right)$ and $\rho$ is the true density $\left(\mathrm{g} / \mathrm{cm}^{3}\right)$ of a nanoparticle [46].

The morphology and size distribution of the synthesized NPs were observed by using transmission electron microscopy (FEI Titan 80-300ST TEM). Selected area electron diffraction (SAED) and energy dispersive X-ray spectroscopy (EDX) in the TEM were used for crystallographic and elemental analysis of NPs. For TEM, nanoparticle samples were diluted with water, dropped onto holey carbon supporting $\mathrm{Cu}$ grids and dried out in air.

\subsection{BMP tests}

Biochemical methane potential tests (BMPs) were performed in triplicate under thermophilic conditions $\left(55^{\circ} \mathrm{C}\right)$. Glass bottles with working and total volumes of 164 and $547 \mathrm{~mL}$ respectively, were used for BMP experiments. Based on the volatile solid content of substrate and inoculum (Table 1), a constant amount of inoculum (i.e., 68.38 g) was mixed with a suspension of $0.47 \mathrm{~g}$ wheat straw in $95.25 \mathrm{~g}$ water so that the substrate to inoculum ratio $(\mathrm{S} / \mathrm{I})$ and initial organic load of substrate for all BMPs set to $2.0 \mathrm{gVS} / \mathrm{gVS}$ and $2.5 \mathrm{gVS} / \mathrm{L}$, respectively. The trace metal salts, iron chloride $\left(\mathrm{FeCl}_{3}\right)$ and nickel chloride $\left(\mathrm{NiCl}_{2}\right)$, were selected for addition at three levels of concentrations based on TS of substrate according to the dosages used in literature $[11,33,48]$. These dosages are in the range of recommended concentrations for digesters mentioned in 
introduction. Based on levels presented in Table 2, level 1 of $\mathrm{FeCl}_{3}$ and $\mathrm{NiCl}_{2}$ contain $0.1 \mathrm{~g} / \mathrm{g}$ TS of Fe and $0.009 \mathrm{~g} / \mathrm{g}$ TS of Ni element, respectively. Trace elements in form of $\mathrm{NPs}, \mathrm{Fe}_{2} \mathrm{O}_{3}-\mathrm{TiO}_{2}$ and $\mathrm{NiO}-\mathrm{TiO}_{2}$, were used as additives in three different dosages. In order to prevent aggregation of NPs and increase their suspension stability, the specific amount of NPs was added to $10 \mathrm{~mL}$ of distilled water and ultra-sonicated for 5 minutes prior to adding them to batch assays. The dosages of $\mathrm{Fe}_{2} \mathrm{O}_{3}-\mathrm{TiO}_{2}$ and $\mathrm{NiO}-\mathrm{TiO}_{2} \mathrm{NPs}$ were calculated according to the amounts of $\mathrm{Fe}$ and $\mathrm{Ni}$ elements in the $\mathrm{FeCl}_{3}$ and $\mathrm{NiCl}_{2}$ additives, respectively (Table 2). As an example, for the level 3 of nickel containing additives, the amount of $\mathrm{Ni}$ element in both $\mathrm{NiCl}_{2}$ and $\mathrm{NiO}-\mathrm{TiO}_{2}$ was equal to 0.9 $\mathrm{mg} / \mathrm{gTS}$. In order to regulate $\mathrm{pH}, 0.1 \mathrm{~g}$ of sodium bicarbonate was added to each bottle. Triplicate of batch reactors containing inoculum, water, and substrate were prepared and incubated in order to determine the biomethane production of mixture in the absence of NPs and salts. In order to provide anaerobic conditions, all bottles were sparged with $\mathrm{N}_{2}$ gas flow for 5 minutes and immediately sealed with butyl rubber stopper and aluminum crimps. The bottles were incubated for 18 days and were shaken manually twice a day during the whole incubation period, in order to ensure homogeneous conditions. Methane concentration was measured twice per week from the headspace of the glass bottles, until the end of process. $5 \mathrm{~mL}$ of the liquid phase was taken from one of the three replicates of each BMP bottles, weekly, for soluble COD and total VFAs analysis.

Table 2. Nanoparticles and trace element salts concentrations supplemented to the biomethane potential (BMP) experiments 


\section{Concentration,}

\begin{tabular}{|c|c|c|c|}
\hline \multirow[t]{2}{*}{ Additive } & \multicolumn{3}{|c|}{ mg of additive/gTS substrate (mg of $\mathrm{Ni}$ or $\mathrm{Fe}$ element/L) } \\
\hline & Level 1 & Level 2 & Level 3 \\
\hline $\mathrm{FeCl}_{3}$ & $0.29(0.269)$ & $2.9(2.69)$ & $29(26.9)$ \\
\hline $\mathrm{NiCl}_{2}$ & $0.02(0.024)$ & $0.2(0.24)$ & $2(2.4)$ \\
\hline $\mathrm{Fe}_{2} \mathrm{O}_{3}-\mathrm{TiO}_{2}(\mathrm{FT})$ & $2.85(0.269)$ & $28.5(2.69)$ & $285(26.9)$ \\
\hline $\mathrm{NiO}-\mathrm{TiO}_{2}(\mathrm{NT})$ & $0.252(0.024)$ & $2.52(0.24)$ & $25.2(2.4)$ \\
\hline
\end{tabular}

\subsection{Analytical methods}

Total solids (TS) and volatile solids (VS), and chemical oxygen demand (COD) were determined according to the Standard Methods [49]. Structural carbohydrates and lignin content of wheat straw were determined according to the procedure reported by Sluiter et al [50]. Volatile fatty acid concentrations (VFAs) were determined using a gaschromatograph (GC-TRACE 1300) equipped with flame ionization detector (FID) and Agilent J \& W capillary Column (30 m x $0.530 \mathrm{~mm}$ i.d., film thickness $1.50 \mu \mathrm{m})$ with helium as carrier gas [51]. The methane concentration in the headspace of the batch reactors was measured using a gas chromatograph (Shimadzu GC-8A) equipped with a flame ionization detector (FID). The volume of produced methane was corrected at STP condition, and BMPs were determined per unit of gVS in the substrate added to each batch reactor. All analytical methods were performed in triplicate and average values were reported.

\subsection{Statistical analysis}

Statistical analysis was applied to all data. Each experiment was conducted three 
times and the average values and standard deviations were calculated. The analysis indicated that the results were similar and there was no significant difference between replicates for each set of experiments. The maximum standard deviations including all data from GC, VFAs, and COD results were $4.33 \mathrm{~mL} \mathrm{CH}_{4} / \mathrm{gVS}, 0.0218 \mathrm{~g} / \mathrm{L}$, and 0.084 $\mathrm{g} / \mathrm{L}$, respectively. In order to compare quantitative variables among different experiments, one-way ANOVA was applied, following Tukey post hoc test $(p<0.05)$.

\section{Results and Discussion}

\subsection{Characterization of nanoparticles}

The crystallographic forms of synthesized NPs were characterized by XRD and SAED in the TEM (Fig. 1). XRD patterns of the $\mathrm{Fe}_{2} \mathrm{O}_{3}-\mathrm{TiO}_{2}$ and $\mathrm{NiO}-\mathrm{TiO}_{2} \mathrm{NPs}$, calcined at $250{ }^{\circ} \mathrm{C}$, are shown in Fig. 1a. The XRD patterns of both NPs have welldeveloped peaks, which correspond to the d-spacings of anatase (JCPDS file No. 211272) or rutile (JCPDS file No. 21-1276). Anatase and rutile phases are marked by A and $\mathrm{R}$, respectively. No significant peaks for $\mathrm{Fe}_{2} \mathrm{O}_{3}$ or $\mathrm{NiO}$ were detected in the $\mathrm{Fe}_{2} \mathrm{O}_{3}$ $\mathrm{TiO}_{2}$ and $\mathrm{NiO}-\mathrm{TiO}_{2} \mathrm{NPs}$. This is probably due to the low content of metal oxide and/or highly dispersion of metal oxides on the surface of $\mathrm{TiO}_{2}$ [52]. Similar observations have been reported in previous works [53]. According to the XRD spectra, the average crystallite sizes $\left(\mathrm{d}_{\mathrm{XRD}}\right)$ of the NPs, using Scherrer's equation, are presented in Table 3. SAED patterns of $\mathrm{Fe}_{2} \mathrm{O}_{3}-\mathrm{TiO}_{2}$ and $\mathrm{NiO}-\mathrm{TiO}_{2}$ NPs are shown in Figs. $1 \mathrm{~b}$ and $1 \mathrm{c}$, respectively. Based on d-spacing values measured from the SAED patterns [54], the distinct diffraction rings were indexed with either rutile or anatase phase [55]. The dspacing values measured with SAED are in excellent agreement with those identified with XRD analysis shown in Fig 1a. No apparent diffraction spots for $\mathrm{Fe}_{2} \mathrm{O}_{3}$ or $\mathrm{NiO}$ 
were observed; suggesting that $\mathrm{Fe}$ or $\mathrm{Ni}$ is present as an amorphous phase and or too small crystallites.
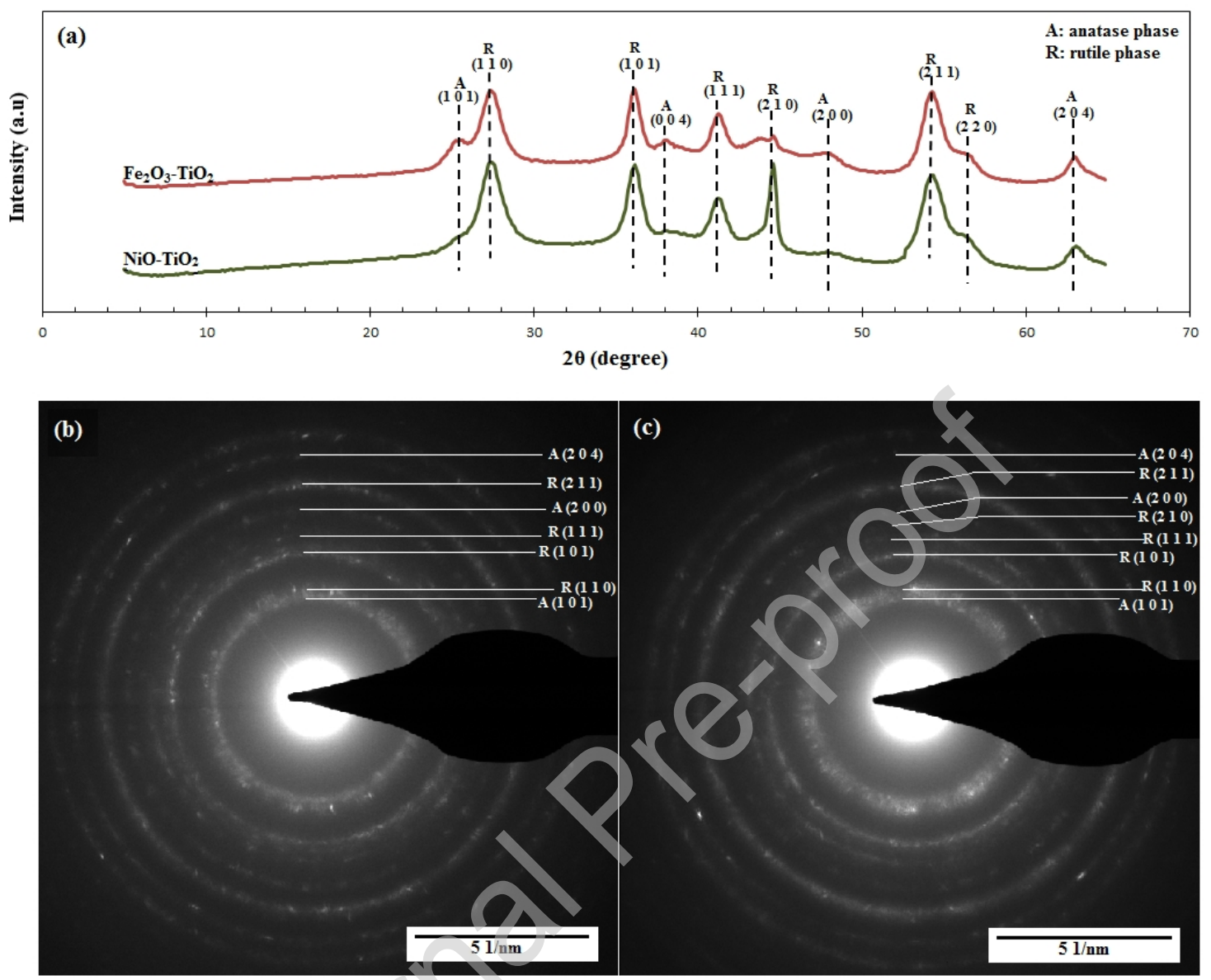

Fig. 1 - X-ray diffraction patterns of $\mathrm{Fe}_{2} \mathrm{O}_{3}-\mathrm{TiO}_{2}$ and $\mathrm{NiO}-\mathrm{TiO}_{2} \mathrm{NPs}(\mathrm{a})$, SAED patterns of $\mathrm{Fe}_{2} \mathrm{O}_{3}-\mathrm{TiO}_{2}$ (b), SAED patterns of $\mathrm{NiO}-\mathrm{TiO}_{2}$ nanoparticles (c).

The BET surface areas of pristine (bare) and metal oxide-coated $\mathrm{TiO}_{2} \mathrm{NPs}$ are presented in Table 3. NPs had surface areas in the range of $120-160 \mathrm{~m}^{2} / \mathrm{g}$. Coating the $\mathrm{TiO}_{2}$ surface with $5 \mathrm{wt} \%$ of $\mathrm{Fe}_{2} \mathrm{O}_{3}$ or $\mathrm{NiO}$ leads to decrease in pore volume and to smaller surface area due to pore blockage with metal oxides [56].

Table 3. Textural and structural features of synthesized nanoparticles 


\begin{tabular}{cccc}
\hline Nanoparticle & BET surface & $\begin{array}{c}\text { Average particle } \\
\text { size measured by }\end{array}$ & $\begin{array}{c}\text { Crystallite size } \\
\text { measured by }\end{array}$ \\
& area $\left(\mathbf{m}^{2} / \mathbf{g}\right)$ & TEM (nm) & XRD (nm) \\
\hline $\mathrm{TiO}_{2}$ & 161 & 8.8 & 9.1 \\
$\mathrm{Fe}_{2} \mathrm{O}_{3}-\mathrm{TiO}_{2}$ & 126 & 11.1 & 10.2 \\
$\mathrm{NiO}_{-}-\mathrm{TiO}_{2}$ & 144 & 9.8 & 9.2 \\
\hline
\end{tabular}

The particle size distributions of $\mathrm{Fe}_{2} \mathrm{O}_{3}-\mathrm{TiO}_{2}$ and $\mathrm{NiO}-\mathrm{TiO}_{2} \mathrm{NPs}$ were obtained by measuring 100 particles from TEM images. Figs. $2 \mathrm{a}$ and $2 \mathrm{~b}$ shows that the particle sizes are somewhat in accordance with the particle size calculated by BET and XRD analysis (Table 3).

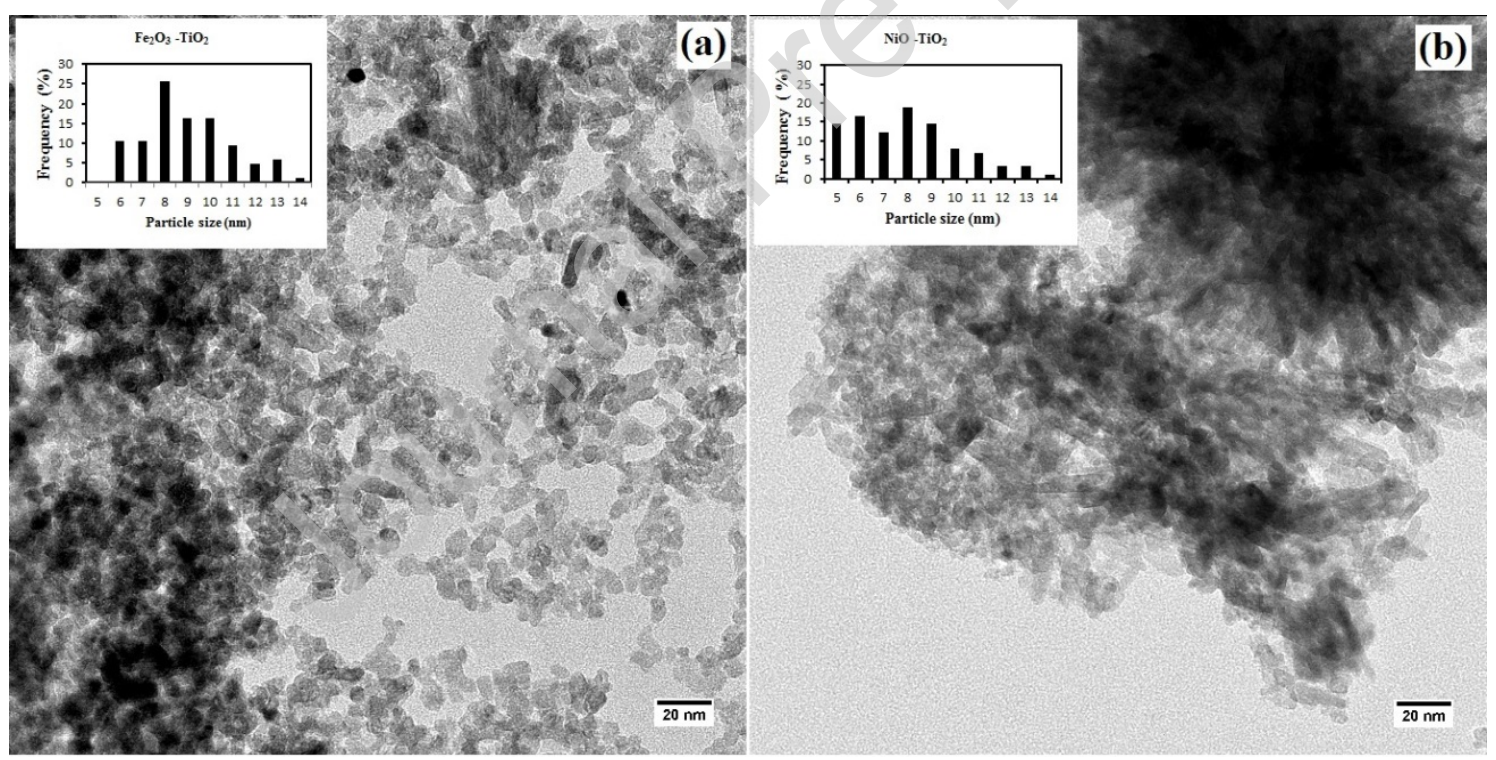

Fig. 2 - TEM micrographs and corresponding particles size distribution (inset) of $\mathrm{Fe}_{2} \mathrm{O}_{3}-\mathrm{TiO}_{2}$ (a) and $\mathrm{NiO}-\mathrm{TiO}_{2}$ (b) nanoparticles.

TEM-EDX spectra of $\mathrm{Fe}_{2} \mathrm{O}_{3}-\mathrm{TiO}_{2}$ and $\mathrm{NiO}-\mathrm{TiO}_{2} \mathrm{NPs}$ shown in Fig. 3 confirms the presence of $\mathrm{Ti}, \mathrm{O}, \mathrm{Ni}$, and $\mathrm{Fe}$ in the NPs. It should be noted that the signals of $\mathrm{Cu}$ and $\mathrm{C}$ 
are from the used TEM grids. Also $\mathrm{Na}$ is due to impurity in the synthesis step. The compositions measured in different regions $(\sim 200 \mathrm{~nm})$ are almost constant, which may imply that $\mathrm{Fe}$ or Ni distributes homogeneously on the surfaces of $\mathrm{TiO}_{2} \mathrm{NPs}$. The small peak for Fe in Fig. $3 b$ probably originates from the microscope pole piece.
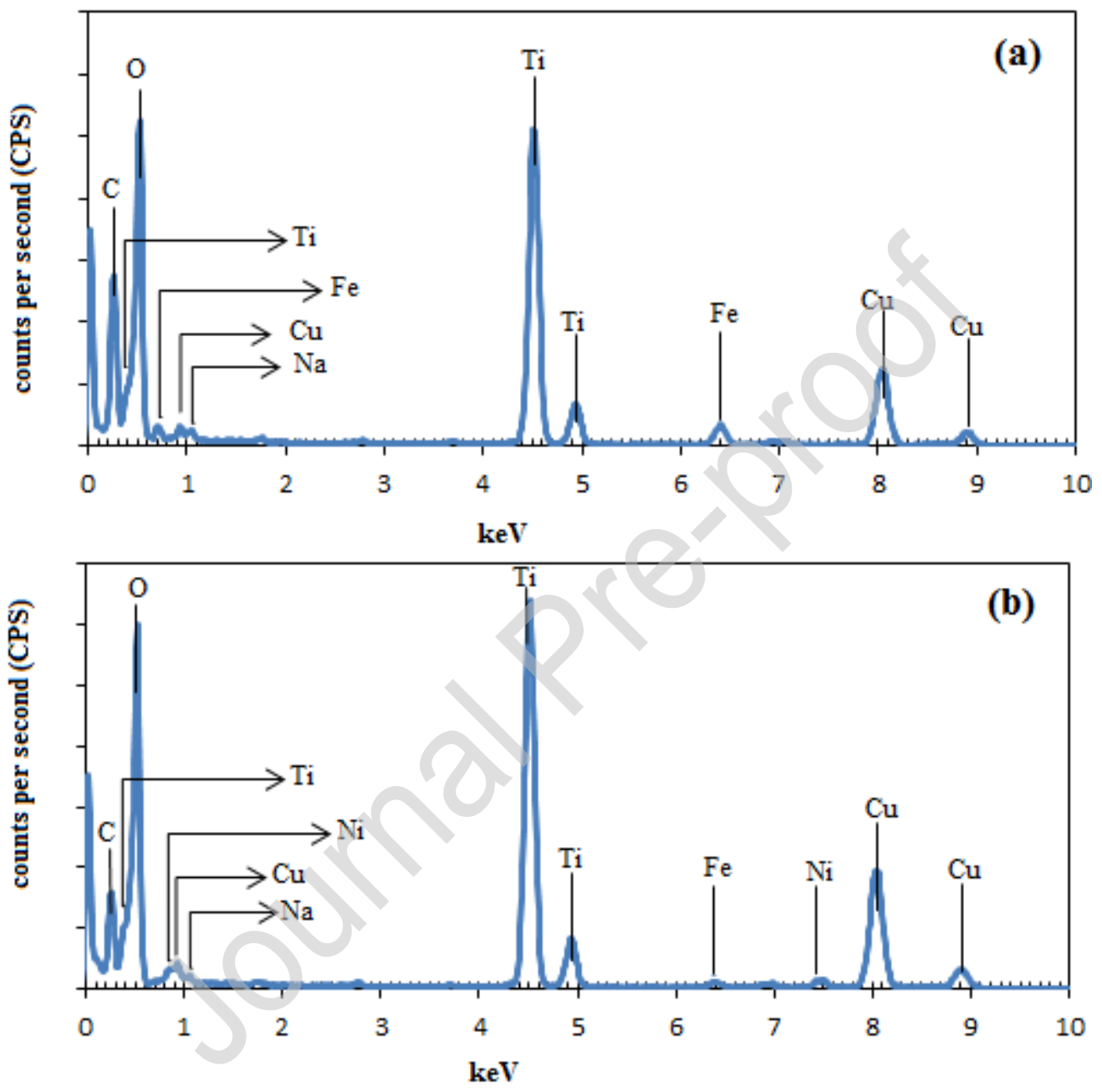

Fig. 3 - EDX spectra of $\mathrm{Fe}_{2} \mathrm{O}_{3}-\mathrm{TiO}_{2}(\mathrm{a})$, and $\mathrm{NiO}-\mathrm{TiO}_{2}$ (b) nanoparticles.

\subsection{Effect on COD and VFAs concentration}

COD and VFAs are important performance indicators for the AD process. Soluble COD and total VFAs concentrations measured during the batch assay testing different dosages of additives are presented in Table 2. Fe was tested at higher concentrations 
compared to $\mathrm{Ni}$ is in accordance to previous reported values showing potential effect [57]. In addition, threshold concentration for toxicity of $\mathrm{Ni}$ is much lower than for Fe [14]. Effect of $\mathrm{Fe}$ and $\mathrm{Ni}$ trace elements in form of salts $\left(\mathrm{FeCl}_{3}\right.$ and $\left.\mathrm{NiCl}_{2}\right)$ and $\mathrm{NPs}$ $\left(\mathrm{Fe}_{2} \mathrm{O}_{3}-\mathrm{TiO}_{2}\right.$ and $\mathrm{NiO}-\mathrm{TiO}_{2}$ compound) on soluble $\mathrm{COD}$ and total VFAs concentrations is illustrated in Fig.4 and Fig. 5, respectively. The COD and VFAs values including the VFA components in the Stacked Graphs were the average values of triplicate measurements.

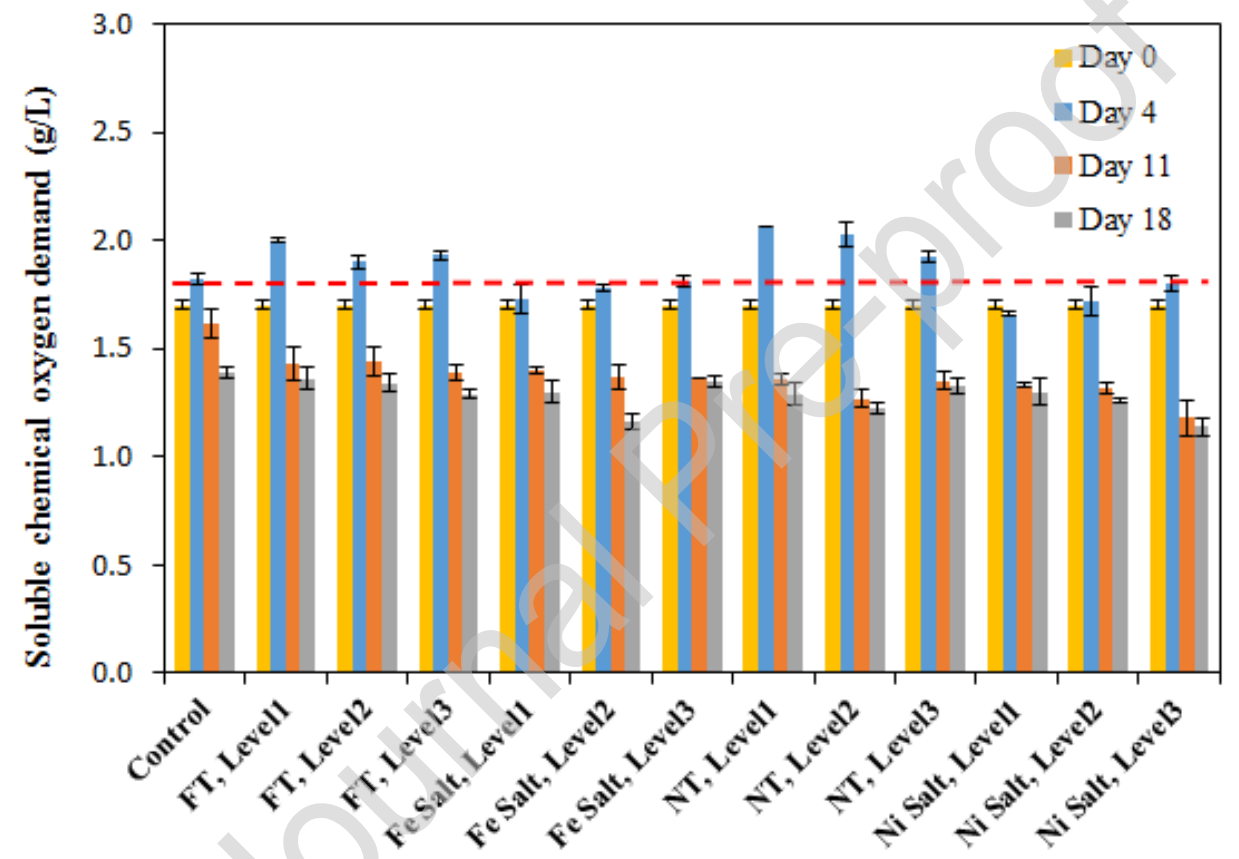

Fig. 4 - Effect of different concentrations of trace elements (in form of $\mathrm{TiO}_{2}$-based $\mathrm{NPs}$ and metal salts) on soluble COD variations. 


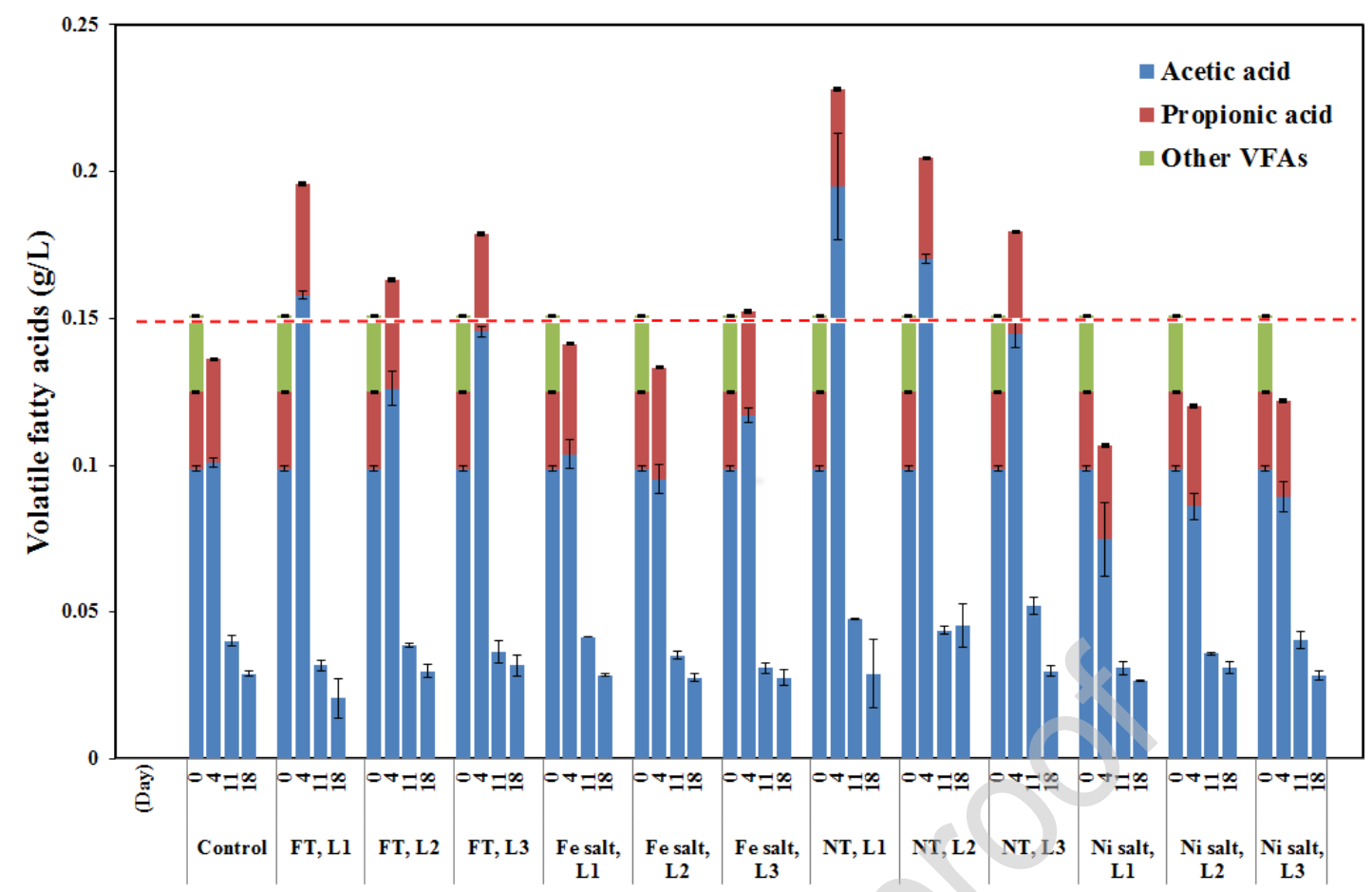

Fig. 5 - Effect of different concentrations of trace elements (in form of $\mathrm{TiO}_{2}$-based $\mathrm{NPs}$ and metal salts) on VFAs variations (L1: level 1, L2: level 2, L3: level 3).

It was observed that in the beginning of the experiment (day 4) the concentrations of soluble COD and total VFAs were higher in case of using $\mathrm{Fe}_{2} \mathrm{O}_{3}-\mathrm{TiO}_{2}$ and $\mathrm{NiO}-\mathrm{TiO}_{2}$ NPs compared to the ones exhibited by the control and salt (i.e. $\mathrm{FeCl}_{3}$ and $\mathrm{NiCl}_{2}$ ) experiments. This indicates that the hydrolysis rate and subsequently acidification degree of substrate was profoundly enhanced by adding NPs. Soluble COD and total VFAs concentration in case of using level 1 of $\mathrm{NiO}_{-} \mathrm{TiO}_{2} \mathrm{NPs}$ at day 4 was $13 \%$ and $67 \%$ higher than that of control at day 4, respectively. Furthermore, Fig. 5 indicates the predominant VFA content during the experiment was acetic acid, followed by propionic acid and trace amount of other VFAs, i.e. butyric and valeric acids. Butyric and longer chain acids were converted before day 4 . Specifically, the maximum acetate concentration $(0.195 \pm 0.0181 \mathrm{~g} / \mathrm{L})$ was found at day 4 in case of using level 1 of NiO- 
$\mathrm{TiO}_{2} \mathrm{NPs}$ which was $95 \%$ higher than that in the control bottle. It is also clear that using NPs caused the accumulation of VFAs content and the hydrolysis of substrate may not have been the rate-limiting step in the AD process of wheat straw. Decomposition and conversion of cellulose and hemicellulose leads to increase in soluble COD and subsequently VFAs concentrations [58]. The mechanism behind the enhancement of soluble COD and VFAs in the presence of metal oxide- $\mathrm{TiO}_{2} \mathrm{NPs}$, probably could be related to the fact that in early days of the process, metal oxide- $\mathrm{TiO}_{2}$ composites accelerate conversion of the accessible macromolecules (cellulose and hemicellulose) into monomers (soluble sugars). Probably, $\mathrm{TiO}_{2}$-based NPs can serve a high surface area to enhance enzymatic activity of hydrolytic enzymes. This is in agreement with the results obtained by Lu et al. [39] confirming that presence of iron oxide-zeolite NPs leads to a higher total VFAs in AD process of cow manure and rice straw. NPs interact with proteinous compounds (i.e enzymes), membranes, cells, DNA, and organelles [59]. The interaction between non-functionalized NPs, i.e. metal-oxide coated $\mathrm{TiO}_{2}$, and biological systems (i.e. enzymes) is based on physical adsorption, related to dipoledipole, hydrophobic, van der Waals, or hydrogen forces [37]. The accumulation of enzymes on the surface of non-toxic NPs enhances enzymatic activity due to higher enzyme density [60]. Furthermore, the effect of $\mathrm{TiO}_{2} \mathrm{NPs}$ on the electron transfer reaction of the activity process of enzyme causes an increase in enzyme activity [61]. Boisset et al. [62] reported that the specific activity of the multi hydrolase enzyme complexes is higher than that of free enzyme systems. Furthermore, Verma and Stellacci (2010) showed that NP surface properties (surface area, shape, and size) affect NP- microorganism interactions and boost bioavailability of lignocellulosic biomass [39]. As it is presented in Table 3, $\mathrm{TiO}_{2}$-based NPs provide a large BET surface area for 
boosted enzymatic activities. There is no significant difference between the COD and VFAs levels of all BMPs in day 11 and also in day 18 . So the difference is in the early days and after that the final levels of COD and VFAs are in the same range for all the experiments. It means almost all of the accessible substrate to enzymes, i.e. cellulose and hemicellulose, is degraded during first 4-5 days of experiment. It is notable that the $\mathrm{pH}$ values for all the BMPs during 18 days of experiments were in the range of 6.5-8.

\subsection{Effect on methane production}

Generally, trace elements are crucial cofactors in many enzymatic reactions involved in biochemistry of methane formation [23]. Fig. 6 illustrates the cumulative production of methane, in the absence and presence of different levels of $\mathrm{Fe}_{2} \mathrm{O}_{3}-\mathrm{TiO}_{2}$ and $\mathrm{NiO}-\mathrm{TiO}_{2}$ NPs and their corresponding salts $\left(\mathrm{FeCl}_{3}\right.$ and $\left.\mathrm{NiCl}_{2}\right)$. Average values of methane production and error bars were calculated based on triplicate measurements.

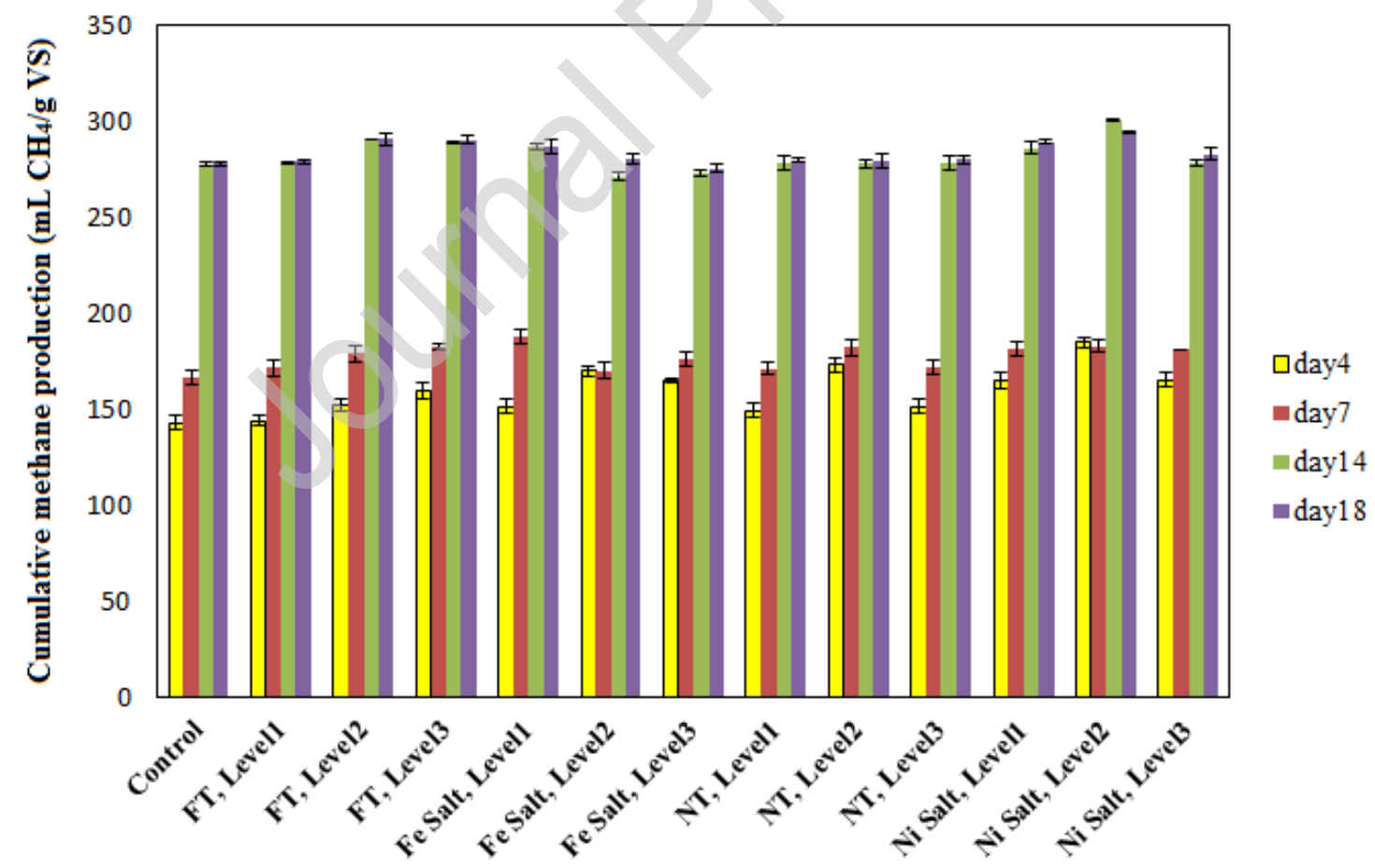

Fig. 6- Effect of different concentrations of $\mathrm{Fe}_{2} \mathrm{O}_{3}-\mathrm{TiO}_{2}$ and $\mathrm{NiO}-\mathrm{TiO}_{2}$ nanoparticles, and $\mathrm{Fe}$ and $\mathrm{Ni}$ salts on the cumulative biomethane production from the $\mathrm{AD}$ of 
wheat straw.

Cumulative methane production of control sample during time was consistent with pervious researches on anaerobic mono-digestion of wheat straw [64,65]. As it can be seen, the addition of NPs and their salts with various concentrations did not result in a significant enhancement of final methane production, and the amount of produced gas at the end of the process is in the same range for all of the additives and levels. This is in agreement with the results obtained by [6] that declaring that trace elements (i.e. Ni, Co, Se) did not result in significant enhancement of the AD of wheat straw. The difference is in first 4 days of experiment, in which adding both salt and NPs has increased the methane production in comparison with control experiments. This can be attributed to the fact that either NPs or corresponding salts can served as cofactors in enzymes which are involved in process of methane formation [58]. Based on results presented in Table 4, cumulative methane production at day 4 was $0.6,6.1$ and $11.4 \%$ more than control experiment when the BMPs conducted respectively in the presence of $2.9 \mathrm{mg} / \mathrm{gTS}$ (level 1), $28.5 \mathrm{mg} / \mathrm{gTS}$ (level 2), and $285 \mathrm{mg} / \mathrm{gTS}$ (level 3) of $\mathrm{Fe}_{2} \mathrm{O}_{3}-\mathrm{TiO}_{2} \mathrm{NPs}$. As it has been presented in Table 2, level 1, level 2, and level 3 of $\mathrm{Fe}_{2} \mathrm{O}_{3}-\mathrm{TiO}_{2} \mathrm{NPs}$ contained 0.3, 2.7 , and $26.9 \mathrm{mg} / \mathrm{L}$ of Fe in solid state. Recommended concentrations of Fe in anaerobic digesters have been reported to be in the range of $1-10 \mathrm{mg} / \mathrm{L}$ [20]. Using the third level of $\mathrm{Fe}_{2} \mathrm{O}_{3}-\mathrm{TiO}_{2}$ NPs, i.e. $285 \mathrm{mg} / \mathrm{gTS}$, had the most profound effect on methane production at first 4 days. It seems that, the accessible $\mathrm{Fe}$ from $\mathrm{Fe}_{2} \mathrm{O}_{3}-\mathrm{TiO}_{2} \mathrm{NPs}$, which is exposed to reaction media, doesn't exceed the recommended range and there is no adverse effect of $\mathrm{Fe}_{2} \mathrm{O}_{3}-\mathrm{TiO}_{2}$ nanoparticle in the present dosing range. NPs act as the carrier and can be first dispersed and then Fe progressively dissolved to supply Fe for 
the microorganisms [1].

Table 4. Percentage of increase in cumulative biomethane production in presence of additives in comparison to control experiments

\begin{tabular}{|c|c|c|c|c|c|}
\hline \multirow{2}{*}{$\begin{array}{l}\text { Type of } \\
\text { additive }\end{array}$} & \multirow[t]{2}{*}{ Dosage } & \multicolumn{4}{|c|}{ comparison with control experiment $(\%)$} \\
\hline & & Day 4 & Day 7 & Day 14 & Day 18 \\
\hline \multirow{3}{*}{$\mathrm{FeCl}_{3}$} & Level 1 & 5.9 & 12.6 & 3.3 & 3.4 \\
\hline & Level 2 & 18.7 & 2.0 & 1.5 & 0.9 \\
\hline & Level 3 & 15.1 & 5.6 & 0.4 & 0.4 \\
\hline \multirow{3}{*}{$\begin{array}{c}\mathrm{Fe}_{2} \mathrm{O}_{3}-\mathrm{TiO}_{2} \\
(\mathrm{FT})\end{array}$} & Level 1 & 0.6 & 2.8 & 0.2 & 0.50 \\
\hline & Level 2 & 6.2 & & 4.6 & 4.7 \\
\hline & Level 3 & 11.4 & 9.4 & 4.0 & 4.2 \\
\hline \multirow{3}{*}{$\mathrm{NiCl}_{2}$} & Level 1 & 15.1 & 8.7 & 2.9 & 4.2 \\
\hline & Level 2 & 29.0 & 9.5 & 8.3 & 5.8 \\
\hline & Level 3 & 15.4 & 8.5 & 0.1 & 1.9 \\
\hline \multirow{3}{*}{$\mathrm{NiO}-\mathrm{TiO}_{2}(\mathrm{NT})$} & Level 1 & 4.4 & 2.6 & 0.2 & 0.6 \\
\hline & Level 2 & 21.1 & 9.2 & 0.1 & 0.6 \\
\hline & Level 3 & 5.9 & 3.2 & 0.3 & 0.8 \\
\hline
\end{tabular}

Positive effect was observed at first 4 days in the presence of $0.29 \mathrm{mg} / \mathrm{gTS}, 2.9$ $\mathrm{mg} / \mathrm{gTS}$, and $29 \mathrm{mg} / \mathrm{gTS}$ of $\mathrm{FeCl}_{3}$. The best performance was observed in case of using level 2 (2.9 mg/gTS) of $\mathrm{FeCl}_{3}$. Appling higher dosage of $\mathrm{FeCl}_{3}$, i.e. $29 \mathrm{mg} / \mathrm{gTS}(26.9$ $\mathrm{mg} \mathrm{Fe} / \mathrm{L}$ ), was not as effective as level 2. This is due to the fact that, addition of metal 
ions with dosages higher than recommended range (1-10 mg Fe/L) leads to less positive effect on AD. At very high concentrations, adverse effect on AD process could be dominant and that can inhibit the biogas production [14]. Similar trend was observed in case of adding $\mathrm{NiO}-\mathrm{TiO}_{2} \mathrm{NPs}$ and $\mathrm{NiCl}_{2}$ salt. Using $2.5 \mathrm{mg} / \mathrm{gTS}$ of $\mathrm{NiO}-\mathrm{TiO}_{2}$ nanoparticle and $0.2 \mathrm{mg} / \mathrm{gTS}$ of $\mathrm{NiCl}_{2}$ resulted in increase of $21.1 \%$ and $29.0 \%$ of methane production at day 4 in comparison with control experiment (Table 4). As it can be seen from Fig. 4 and Fig. 5, the NiO-TiO 2 NPs effectively increased the hydrolysis of substrate. The concentration of soluble COD and total VFAs at day 4 in case of using $\mathrm{NiO}-\mathrm{TiO}_{2}$ is more than that of $\mathrm{NiCl}_{2}$; while as it can be seen in Table 4 the methane production in case of using $\mathrm{NiCl}_{2}$ is higher than that of $\mathrm{NiO}-\mathrm{TiO}_{2}$ during first 4 days of experiments. This means that, $\mathrm{NiCl}_{2}$ probably could stimulate the methanogenesis more effective than $\mathrm{NiO}-\mathrm{TiO}_{2} \mathrm{NPs}$ when Ni content is equal for both forms, i.e. NPs and salt. This is due to the fact that the bioavailability of Ni for microorganisms in form of NPs is less than its bioavailability in form of salt. The content of Ni metal ions $(1 \pm 0 \mu \mathrm{g} / \mathrm{g}$ VS of substrate) found in the wheat straw was lower than that of Fe $(41 \pm 2.3 \mu \mathrm{g} / \mathrm{g} \mathrm{VS}$ of substrate). Using level 3 of both $\mathrm{NiO}-\mathrm{Fe}_{2} \mathrm{O}_{3} \mathrm{NPs}$ and $\mathrm{NiCl}_{2}$ salts ( $\mathrm{Ni}$ contents is equal to $2.4 \mathrm{mg} / \mathrm{L}$ ) had lower positive effect in comparison to level 2 . This is probably due to the toxic effect of $\mathrm{Ni}$ as trace element. This is in agreement with the results obtained by Schattauer et al. [23] indicating that Ni element concentration in range of 0.005-0.5 $\mathrm{mg} / \mathrm{L}$ is recommended for anaerobic digesters. Exceeding this range could have inhibitory effect on AD process. Bożym et al. [66] reported that the toxic threshold for nickel in fermented wastes is equal to $10 \mathrm{mg} / \mathrm{L}$. The toxic effect of heavy trace elements (i.e. $\mathrm{Fe}, \mathrm{Ni}, \mathrm{Co}, \mathrm{Mo}, \mathrm{Cu}$ ) is due to the chemical binding of these metals to the enzymes and microorganisms, leading to the disruption of enzyme structure and activities [67]. 
At relatively high concentrations, heavy metals can form unspecific compounds, altering the optimum biochemistry and performance of the processes [68]. These results indicate that the best concentrations of $\mathrm{Fe}_{2} \mathrm{O}_{3}-\mathrm{TiO}_{2}$ and $\mathrm{NiO}-\mathrm{Fe}_{2} \mathrm{O}_{3} \mathrm{NPs}$ and $\mathrm{FeCl}_{3}$ and $\mathrm{NiCl}_{2}$ salts are $285,2.52,29$, and $0.2 \mathrm{mg} / \mathrm{gTS}(\mathrm{p}<0.05)$, respectively. The large difference between amounts of $\mathrm{Fe}$ containing additives (i.e. $\mathrm{Fe}_{2} \mathrm{O}_{3}-\mathrm{TiO}_{2} \mathrm{NPs}$ and $\mathrm{FeCl}_{3}$ salt) and $\mathrm{Ni}$ containing additives (i.e. $\mathrm{NiO}-\mathrm{TiO}_{2} \mathrm{NPs}_{\mathrm{s}}$ and $\mathrm{NiCl}_{2}$ salt) is due to the fact that microorganisms require much more Fe concentration than $\mathrm{Ni}$ [23].

\section{Conclusions}

Highly surface area $\mathrm{Fe}_{2} \mathrm{O}_{3}-\mathrm{TiO}_{2}$ and $\mathrm{NiO}-\mathrm{TiO}_{2}$ nanoparticles were synthesized and characterized to be evaluated in the $\mathrm{AD}$ of wheat straw. The effects of $\mathrm{Fe}$ and $\mathrm{Ni}$ in the form of $\mathrm{TiO}_{2}$-based $\mathrm{NPs}$ and their salts, i.e. $\mathrm{FeCl}_{3}$ and $\mathrm{NiCl}_{2}$, were investigated for three different dosages. The results showed an enhancement in production of soluble COD up to $13 \%$ and total VFAs up to $67 \%$ with the addition of NPs during first 4 days of experiments. Coating high surface area $\mathrm{TiO}_{2} \mathrm{NPs}$ with trace metals, gives promising prospects to promote $\mathrm{AD}$ process of feedstocks with harsh conversion. As future works, coating of several trace elements in form of NPs on surface of recyclable cm-scale pellet of $\mathrm{TiO}_{2}$ would be of great interest as well as the application of these multi-component structures at mesophilic temperature condition that could be used on the industrial scale production.

\section{References}

[1] Casals E, Barrena R, García A, González E, Delgado L, Busquets-Fité M, et al. Programmed iron oxide nanoparticles disintegration in anaerobic digesters boosts 
biogas production. Small 2014;10:2801-8.

[2] Appels L, Van Assche A, Willems K, Degrève J, Van Impe J, Dewil R. Peracetic acid oxidation as an alternative pre-treatment for the anaerobic digestion of waste activated sludge. Bioresour Technol 2011;102:4124-30.

[3] Gonçalves G, Mori Y, Kamiya N. Biomolecular assembly strategies to develop potential artificial cellulosomes. Sustain Chem Process 2014;2:19. doi:10.1186/s40508-014-0019-9.

[4] Claassen PAM, van Lier JB, Lopez Contreras AM, van Niel EWJ, Sijtsma L, Stams AJM, et al. Utilisation of biomass for the supply of energy carriers. Appl Microbiol Biotechnol 1999;52:741-55. doi:10.1007/s002530051586.

[5] Shoham Y, Lamed R, Bayer EA. The cellulosome concept as an efficient microbial strategy for the degradation of insoluble polysaccharides. Trends Microbiol 1999;7:275-81. doi:10.1016/S0966-842X(99)01533-4.

[6] Mancini G, Papirio S, Lens PNL, Esposito G. Increased biogas production from wheat straw by chemical pretreatments. Renew Energy 2018;119:608-14. doi:10.1016/j.renene.2017.12.045.

[7] Zhang Y, Kang X, Wang Z, Kong X, Li L, Sun Y, et al. Enhancement of the energy yield from microalgae via enzymatic pretreatment and anaerobic codigestion. Energy 2018;164:400-7.

[8] Wang Y, Ren G, Zhang T, Zou S, Mao C, Wang X. Effect of magnetite powder on anaerobic co-digestion of pig manure and wheat straw. Waste Manag 2017;66:46-52. doi:10.1016/j.wasman.2017.04.031.

[9] Liu L, Zhang T, Wan H, Chen Y, Wang X, Yang G, et al. Anaerobic co-digestion of animal manure and wheat straw for optimized biogas production by the 
addition of magnetite and zeolite. Energy Convers Manag 2015;97:132-9.

[10] Voelklein MA, O’Shea R, Jacob A, Murphy JD. Role of trace elements in single and two-stage digestion of food waste at high organic loading rates. Energy 2017;121:185-92.

[11] Abdelsalam E, Samer M, Attia YA, Abdel-Hadi MA, Hassan HE, Badr Y. Effects of Co and Ni nanoparticles on biogas and methane production from anaerobic digestion of slurry. Energy Convers Manag 2017;141:108-19. doi:10.1016/j.enconman.2016.05.051.

[12] Kim M, Gomec CY, Ahn Y, Speece RE. Hydrolysis and acidogenesis of particulate organic material in mesophilic and thermophilic anaerobic digestion. Environ Technol 2003;24:1183-90.

[13] Zandvoort MH, van Hullebusch ED, Fermoso FG, Lens PNL. Trace metals in anaerobic granular sludge reactors: Bioavailability and dosing strategies. Eng Life Sci 2006;6:293-301. doi:10.1002/elsc.200620129.

[14] Mudhoo A, Kumar S. Effects of heavy metals as stress factors on anaerobic digestion processes and biogas production from biomass. Int J Environ Sci Technol 2013;10:1383-98. doi:10.1007/s13762-012-0167-y.

[15] Ma D, Wang J, Chen T, Shi C, Peng S, Yue Z. Iron-oxide-promoted anaerobic process of the aquatic plant of curly leaf pondweed. Energy \& Fuels 2015;29:4356-60.

[16] Zhang Y, Feng Y, Yu Q, Xu Z, Quan X. Enhanced high-solids anaerobic digestion of waste activated sludge by the addition of scrap iron. Bioresour Technol 2014;159:297-304.

[17] Shi C, Wang J, Peng S, Hou C, Chen T, Yue Z. Fe3+ enhanced anaerobic 
digestion process of corn straw. Trans Chinese Soc Agric Eng 2013;29:218-25.

[18] Diekert G, Konheiser U, Piechulla K, Thauer RK. Nickel requirement and factor F430 content of methanogenic bacteria. J Bacteriol 1981;148:459-64.

[19] Ashley N V, Davies M, Hurst TMRJ. the Effect of Increased Nickel Ion Concentrations on Microbial Populations in 1982;16.

[20] Weiland P. Anforderungen an Pflanzen seitens des Biogasanlagenbetreibers, TLL-Jena, Eigenverlag, 12. Thüringer Bioenergietag 2006:26-32.

[21] Austermann-Haun U, Seyfried CF, Bode B. Anaerobe Verfahren zur Behandlung von Industrieabwässern n.d.

[22] Mudrack K, Kunst S. Biologie der Abwasserreinigung. Fischer; 1985.

[23] Schattauer A, Abdoun E, Weiland P, Plöchl M, Heiermann M. Abundance of trace elements in demonstration biogas plants. Biosyst Eng 2011;108:57-65.

[24] Kloss R. Planung von Biogasanlagen nach technisch-wirtschaftlichen Kriterien: Stand des Wissens, Stand der Technik in der Landwirtschaft; Planungsmodell; mit Hinweisen für die Planung abwassertechnischer Anlagen. Oldenbourg; 1986.

[25] Zhang Y, Zhang Z, Suzuki K, Maekawa T. Uptake and mass balance of trace metals for methane producing bacteria. Biomass and Bioenergy 2003;25:427-33.

[26] Altaş L. Inhibitory effect of heavy metals on methane-producing anaerobic granular sludge. J Hazard Mater 2009;162:1551-6.

[27] Wu D, Yang Z, Tian G. Inhibitory effects of Cu (II) on fermentative methane production using bamboo wastewater as substrate. J Hazard Mater $2011 ; 195: 170-4$.

[28] Demirel B, Scherer P. Trace element requirements of agricultural biogas digesters during biological conversion of renewable biomass to methane. 
Biomass and Bioenergy 2011;35:992-8.

[29] Wang T, Zhang D, Dai L, Chen Y, Dai X. Effects of metal nanoparticles on methane production from waste-activated sludge and microorganism community shift in anaerobic granular sludge. Sci Rep 2016;6:1-10. doi:10.1038/srep25857.

[30] Hussein AK. Applications of nanotechnology in renewable energies-A comprehensive overview and understanding. Renew Sustain Energy Rev $2015 ; 42: 460-76$.

[31] Villaseñor MJ, Ríos Á. Nanomaterials for water cleaning and desalination, energy production, disinfection, agriculture and green chemistry. Environ Chem Lett 2017:1-24.

[32] Luna-delRisco M, Orupõld K, Dubourguier H-C. Particle-size effect of CuO and $\mathrm{ZnO}$ on biogas and methane production during anaerobic digestion. J Hazard Mater 2011;189:603-8.

[33] Abdelsalam E, Samer M, Attia YA, Abdel-Hadi MA, Hassan HE, Badr Y. Comparison of nanoparticles effects on biogas and methane production from anaerobic digestion of cattle dung slurry. Renew Energy 2016;87:592-8. doi:10.1016/j.renene.2015.10.053.

[34] Abdelsalam E, Samer M, Attia YA, Abdel-Hadi MA, Hassan HE, Badr Y. Influence of zero valent iron nanoparticles and magnetic iron oxide nanoparticles on biogas and methane production from anaerobic digestion of manure. Energy 2017; 120:842-53.

[35] Faisal S, Yusuf Hafeez F, Zafar Y, Majeed S, Leng X, Zhao S, et al. A Review on Nanoparticles as Boon for Biogas Producers_-Nano Fuels and Biosensing Monitoring. Appl Sci 2019;9:59. 
[36] Yang Y, Zhang C, Hu Z. Impact of metallic and metal oxide nanoparticles on wastewater treatment and anaerobic digestion. Environ Sci Process Impacts 2012;15:39-48.

[37] Chen M, Zeng G, Xu P, Lai C, Tang L. How Do Enzymes 'Meet' Nanoparticles and Nanomaterials? Trends Biochem Sci 2017;42:914-30. doi:10.1016/j.tibs.2017.08.008.

[38] Mu H, Chen Y, Xiao N. Effects of metal oxide nanoparticles (TiO2, A12O3, $\mathrm{SiO} 2$ and $\mathrm{ZnO}$ ) on waste activated sludge anaerobic digestion. Bioresour Technol 2011;102:10305-11.

[39] Lu X, Wang H, Ma F, Zhao G, Wang S. Enhanced anaerobic digestion of cow manure and rice straw by the supplementation of an iron oxide-zeolite system. Energy and Fuels 2017;31:599-606. doi:10.1021/acs.energyfuels.6b02244.

[40] Baniamerian H, Isfahani PG, Tsapekos P, Alvarado-Morales M, Shahrokhi M, Vossoughi M, et al. Application of nano-structured materials in anaerobic digestion: Current status and perspectives. Chemosphere 2019.

[41] Astruc D, Lu F, Aranzaes JR. Nanoparticles as recyclable catalysts: The frontier between homogeneous and heterogeneous catalysis. Angew Chemie - Int Ed 2005;44:7852-72. doi:10.1002/anie.200500766.

[42] Gonzalez-Estrella J, Sierra-Alvarez R, Field JA. Toxicity assessment of inorganic nanoparticles to acetoclastic and hydrogenotrophic methanogenic activity in anaerobic granular sludge. J Hazard Mater 2013;260:278-85. doi:10.1016/j.jhazmat.2013.05.029.

[43] García A, Delgado L, Torà JA, Casals E, González E, Puntes V, et al. Effect of cerium dioxide, titanium dioxide, silver, and gold nanoparticles on the activity of 
microbial communities intended in wastewater treatment. J Hazard Mater 2012;199:64-72.

[44] Moset V, Poulsen M, Wahid R, Højberg O, Møller HB. Mesophilic versus thermophilic anaerobic digestion of cattle manure: methane productivity and microbial ecology. Microb Biotechnol 2015;8:787-800.

[45] Labatut RA, Angenent LT, Scott NR. Conventional mesophilic vs. thermophilic anaerobic digestion: a trade-off between performance and stability? Water Res 2014;53:249-58.

[46] Baniamerian H, Safavi M, Alvarado-Morales M, Tsapekos P, Angelidaki I, Shokrollahzadeh S. Photocatalytic inactivation of Vibrio fischeri using Fe 2 O 3TiO 2-based nanoparticles. Environ Res 2018;166:497-506.

[47] Firooz AA, Mahjoub AR, Khodadadi AA, Movahedi M. High photocatalytic activity of $\mathrm{Zn} 2 \mathrm{SnO} 4$ among various nanostructures of $\mathrm{Zn} 2 \mathrm{xSn} 1-\mathrm{xO} 2$ prepared by a hydrothermal method. Chem Eng J 2010;165:735-9. doi:10.1016/j.cej.2010.09.052.

[48] Mancini G, Papirio S, Riccardelli G, Lens PNL, Esposito G. Trace elements dosing and alkaline pretreatment in the anaerobic digestion of rice straw. Bioresour Technol 2018;247:897-903. doi:10.1016/j.biortech.2017.10.001.

[49] Apha. Standard methods for the examination of water and wastewater. Apha; 1985.

[50] Sluiter A, Hames B, Ruiz R, Scarlata C, Sluiter J, Templeton D, et al. Determination of structural carbohydrates and lignin in biomass. Lab Anal Proced 2008;1617:1-16.

[51] Khoshnevisan B, Tsapekos P, Alvarado-Morales M, Angelidaki I. Process 
performance and modelling of anaerobic digestion using source-sorted organic household waste. Bioresour Technol 2018;247:486-95.

doi:10.1016/j.biortech.2017.09.122.

[52] Dong X, Tao J, Li Y, Zhu H. Oriented single crystalline TiO2 nano-pillar arrays directly grown on titanium substrate in tetramethylammonium hydroxide solution. Appl Surf Sci 2010;256:2532-8. doi:10.1016/j.apsusc.2009.10.100.

[53] Banisharif A, Khodadadi AA, Mortazavi Y, Anaraki Firooz A, Beheshtian J, Agah S, et al. Highly active Fe2O3-doped TiO2 photocatalyst for degradation of trichloroethylene in air under UV and visible light irradiation: Experimental and computational studies. Appl Catal B Environ 2015;165:209-21. doi:10.1016/j.apcatb.2014.10.023.

[54] David B. Williams., Carter CB. Transmission electron microscopy. 2009.

[55] Rehan M, Lai X, Kale GM. Hydrothermal synthesis of titanium dioxide nanoparticles studied employing in situ energy dispersive X-ray diffraction. CrystEngComm 2011;13:3725. doi:10.1039/c0ce00781a.

[56] Adán C, Bahamonde A, Fernández-García M, Martínez-Arias A. Structure and activity of nanosized iron-doped anatase $\mathrm{TiO} 2$ catalysts for phenol photocatalytic degradation. Appl Catal B Environ 2007;72:11-7.

doi:10.1016/j.apcatb.2006.09.018.

[57] Worm P, Fermoso FG, Lens PNL, Plugge CM. Decreased activity of a propionate degrading community in a UASB reactor fed with synthetic medium without molybdenum, tungsten and selenium. Enzyme Microb Technol 2009;45:139-45. doi:10.1016/j.enzmictec.2009.02.001.

[58] Juntupally S, Begum S, Allu SK, Nakkasunchi S, Madugula M, Anupoju GR. 
Relative evaluation of micronutrients $(\mathrm{MN})$ and its respective nanoparticles (NPs) as additives for the enhanced methane generation. Bioresour Technol 2017;238:290-5. doi:10.1016/j.biortech.2017.04.049.

[59] Nel AE, Mädler L, Velegol D, Xia T, Hoek EMV, Somasundaran P, et al. Understanding biophysicochemical interactions at the nano-bio interface. Nat Mater 2009;8:543-57. doi:10.1038/nmat2442.

[60] Ding S, Cargill AA, Medintz IL, Claussen JC. Increasing the activity of immobilized enzymes with nanoparticle conjugation. Curr Opin Biotechnol 2015;34:242-50. doi:10.1016/j.copbio.2015.04.005.

[61] Zhang H-M, Cao J, Tang B-P, Wang Y-Q. Effect of TiO2 nanoparticles on the structure and activity of catalase. Chem Biol Interact 2014;219:168-74.

[62] Boisset C, Chanzy H, Henrissat B, Lamed R, Shoham Y, Bayer EA. Digestion of crystalline cellulose substrates by the clostridium thermocellum cellulosome: structural and morphological aspects. Biochem J 1999;835:829-35. doi:10.1042/0264-6021:3400829.

[63] Verma A, Stellacci F. Effect of surface properties on nanoparticle-cell interactions. Small 2010;6:12-21.

[64] Liu X, Zicari SM, Liu G, Li Y, Zhang R. Improving the bioenergy production from wheat straw with alkaline pretreatment. Biosyst Eng 2015;140:59-66.

[65] Awais M, Alvarado-Morales M, Tsapekos P, Gulfraz M, Angelidaki I. Methane production and kinetic modeling for co-digestion of manure with lignocellulosic residues. Energy \& Fuels 2016;30:10516-23.

[66] Bożym M, Florczak I, Zdanowska P, Wojdalski J, Klimkiewicz M. An analysis of metal concentrations in food wastes for biogas production. Renew Energy 
2015;77:467-72.

[67] Wani PA, Khan MS, Zaidi A. Toxic effects of heavy metals on germination and physiological processes of plants. Toxic. heavy Met. to Legum. bioremediation, Springer; 2012, p. 45-66.

[68] Kavamura VN, Esposito E. Biotechnological Strategies Applied to the Decontamination of Soils Polluted with Heavy Metals. Compr Biotechnol Second Ed 2011;6:197-206. doi:10.1016/B978-0-08-088504-9.00371-8. 


\section{Highlights}

- $\mathrm{TiO}_{2}$ nanoparticles (NPs) coated with $\mathrm{Fe}_{2} \mathrm{O}_{3}$ or $\mathrm{NiO}$ were synthesized and characterized

- The effects of trace metals were tested on anaerobic digestion of wheat straw

- Up to $13 \%$ increase in soluble COD is observed due to increase of hydrolysis rate

- Total VFAs production rate increased up to $67 \%$ using NPs

- NPs and salts boosted methane production rate up to $21.1 \%$ and $29 \%$, respectively 